\title{
APPLICATION OF DISRUPTIVE TECHNOLOGIES ON ENVIRONMENTAL HEALTH: AN OVERVIEW OF ARTIFICIAL INTELLIGENCE, BLOCKCHAIN AND INTERNET OF THINGS
}

\author{
Anuj Kumar*1, Geetika Madaan², Pooja Sharma³, Arya Kumar4 \\ 1. Apeejay School of Management, Dwarka, Delhi, India \\ 2. University Center for Research and Development, Chandigarh University, India \\ 3. University School of Business, Chandigarh University, India \\ 4. KIIT School of Commerce and Economics, Kalinga Institute of Industrial Technology (Deemed to be University), Bhubaneswar, \\ India
}

Correspondence: anujsmooth@gmail.com

\begin{abstract}
Environmental monitoring technology is a critical component in assisting and ensuring environmental management success. The development patterns of disruptive technologies for environmental monitoring should be studied and anticipated in order to aid in the promotion of India's environmental monitoring and protection. The primary objective is to examine previous research on disruptive technology and its current environmental applications, as well as to determine the degree of connection between the chosen variables, using the Vos Viewer Software, which is being used in this study. A discussion of the existing environmental impacts associated with artificial intelligence (Al), blockchain, and the Internet of Things (loT), as well as new advancements in these fields, is presented in this article. As a result of the research, the difficulties and possibilities presented by the stated technologies on the entire Indian environmental monitoring network have been highlighted that can be useful for researchers and government for future advancement in environmental health.
\end{abstract}

\section{KEYWORDS}

artificial intelligence; blockchain; disruptive technologies; environment; internet of things; health; monitoring

\section{INTRODUCTION}

Environmental data gathering has been simplified and enhanced via the use of information management, networking technologies, and technological advancements. As one example, cloud computing capacity for data storage now enables continuous data gathering through lightweight sensors. The knowledge collected, however, is often not used correctly. However, low-cost data storage and growing computer power (especially technical computing capability) may assist 
create an extensive collection of environmental datasets with untapped potential. [1]

Investigations and study have suggested that modern technology should be included in the scope of climate change and that pan-Indian surveillance and monitoring methods be established to promote environmental protection. Academics, legislators, and environmental authorities all have access to analytical tools to develop ideas from open data, and these methods include evidence from various ecosystems of environmental data. [2]

In the future, these techniques may benefit from several new technologies, such as the Internet of Things, cloud computing, "Artificial Intelligence," "Blockchain," "Machine Learning," and "Deep Learning," among others. Many fields involving Comprehensive statistics, such as "influenza control" and "air quality monitoring," have benefited from these ground-breaking innovations, which have the potential to greatly facilitate the establishment of a panIndian surveillance mechanism, as demonstrated by their widespread application [3]. As environment is changing quickly and affecting wellbeing of people around the world, we must now adjust to this shift and cope with new demands on the environment monitoring system. [4]
It is the purpose of this article to explore new efforts to solve some of the issues using creative technologies. Prior literature is reviewed, as well as its application in the Indian environmental and health monitoring framework, and potential problems that may arise in the process of incorporating the proposed Pan-Indian Monitoring System components are discussed. The goal of the study is to offer a variety of descriptions of the current and future applications of these technologies in the environmental health. [5]

\section{RESEARCH METHODOLOGY}

The current research was carried out utilizing descriptive analysis. The researchers developed a schematic representation (see Figure 1) adopted from [6] to demonstrate method for choosing papers and to indicate the need for exploring the ways to ensure development of monitoring, surveillance, and environmental health related activities by integrating Artificial Intelligence, Blockchain, and Internet of Things. The current study followed the criteria for schematic representation as existing research striving for greater accuracy. [6] The stages for a systematic review are outlined in this context (as mentioned in table1):

\section{TABLE 1: FORMULATION OF RESEARCH DESIGN}

\section{RESEARCH METHODS}

\begin{tabular}{|l|l|}
\hline Research Question & $\begin{array}{l}\text { In this study, we sought to answer the question, "How disruptive technologies based } \\
\text { on Artificial Intelligence, Blockchain, and the Internet of Things would aid } \\
\text { environmental health research?" }\end{array}$ \\
\hline Articles searching & A collection of articles from academic databases (PubMed and IEEE). \\
\hline Study design & $\begin{array}{l}\text { A wide range of papers, including randomised controlled trials, cross-sectional, } \\
\text { meta-analytic, and systematic review investigations, were analysed. }\end{array}$ \\
\hline Sources of Data collection & $\begin{array}{l}\text { The examination of earlier research on the use of several disruptive technologies in } \\
\text { environmental health and the climate to gather data for the current study. }\end{array}$ \\
\hline Variables Assessed & $\begin{array}{l}\text { In the end, the articles are analysed and a number of indicators are obtained. In } \\
\text { addition to: "Internet of Things" "Blockchain", "Artificial Intelligence", "environmental } \\
\text { health". }\end{array}$ \\
\hline $\begin{array}{l}\text { The compilation, Results, and } \\
\text { monitoring }\end{array}$ & $\begin{array}{l}\text { In order to better understand environmental and health data, we look at the most } \\
\text { recent breakthroughs and challenges in disruptive technology. }\end{array}$ \\
\hline
\end{tabular}




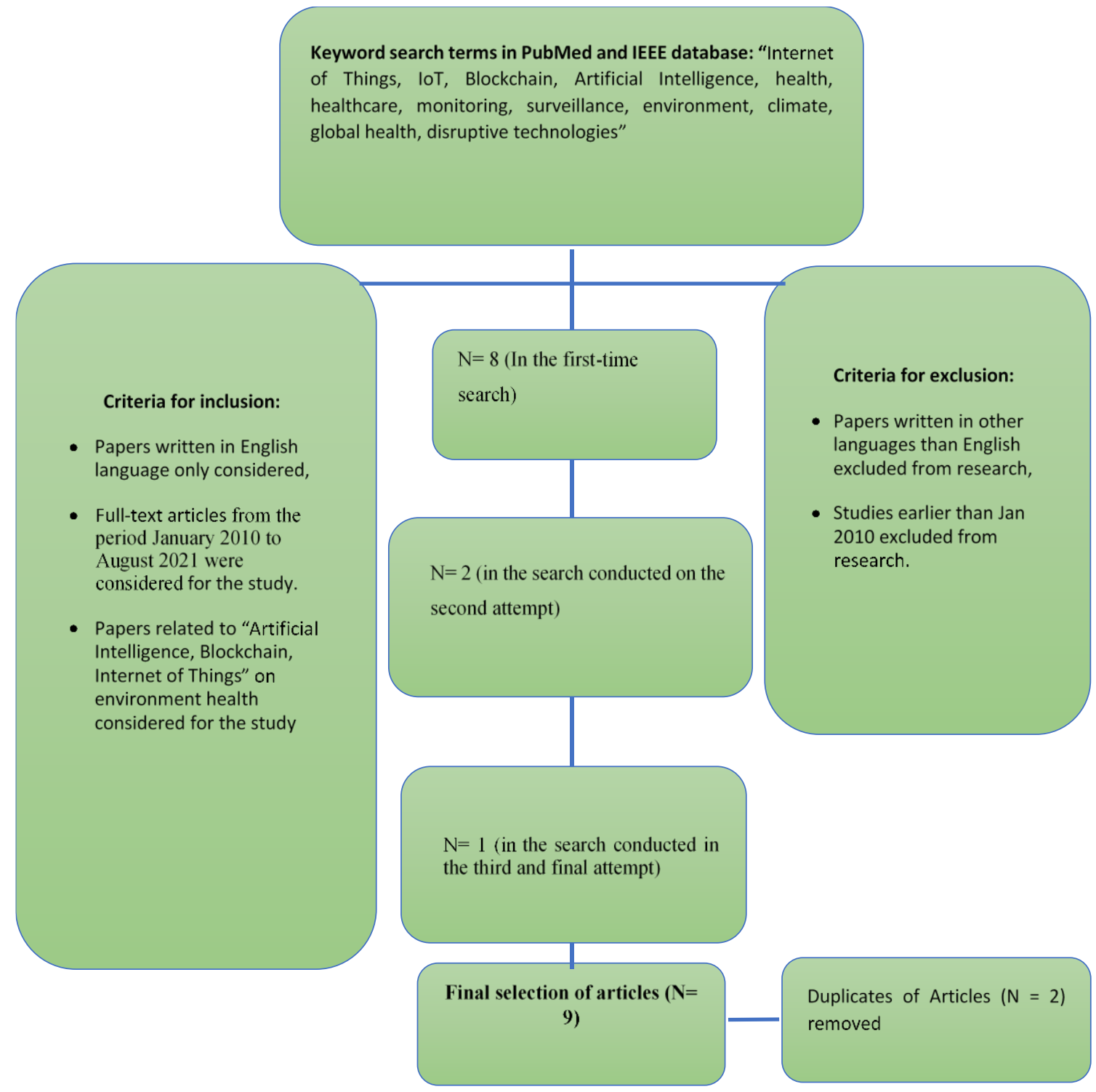

\section{RESULT}

A close examination of many academic publications and government research, including "Internet of Things, Blockchain, and Artificial Intelligence" may generate enormous potential for environmental information promotion. This investigation used the Vos Viewer software version 1.6.15 to try to discover the degree of connection between the factors examined by the researchers in the chosen publications. As a first step, researchers mapped out the most commonly used terms in their publications using a keyword frequency database. (As shown in Figure 2), and a network representation of the most frequently used keywords in the chosen articles is shown in Figure 3.
The creation of clusters was discovered using a keyword mapping from the previous research. A clustering model was created and displayed 3 clusters, as shown in Table 2.

The research found that the most powerful terms generated in Vos Viewer software had a mapping to specific keywords with the greatest frequency (figure 4). The network visualization revealed how influential the most important terms collected from the chosen articles were connected to one another. Strong associations among terms including "artificial intelligence," "internet of things," "blockchain," and with "environmental health" were identified, with being the most significan 
FIGURE 2: PLOTTING OF KEYWORD DISTRIBUTION IN SELECTED ARTICLES

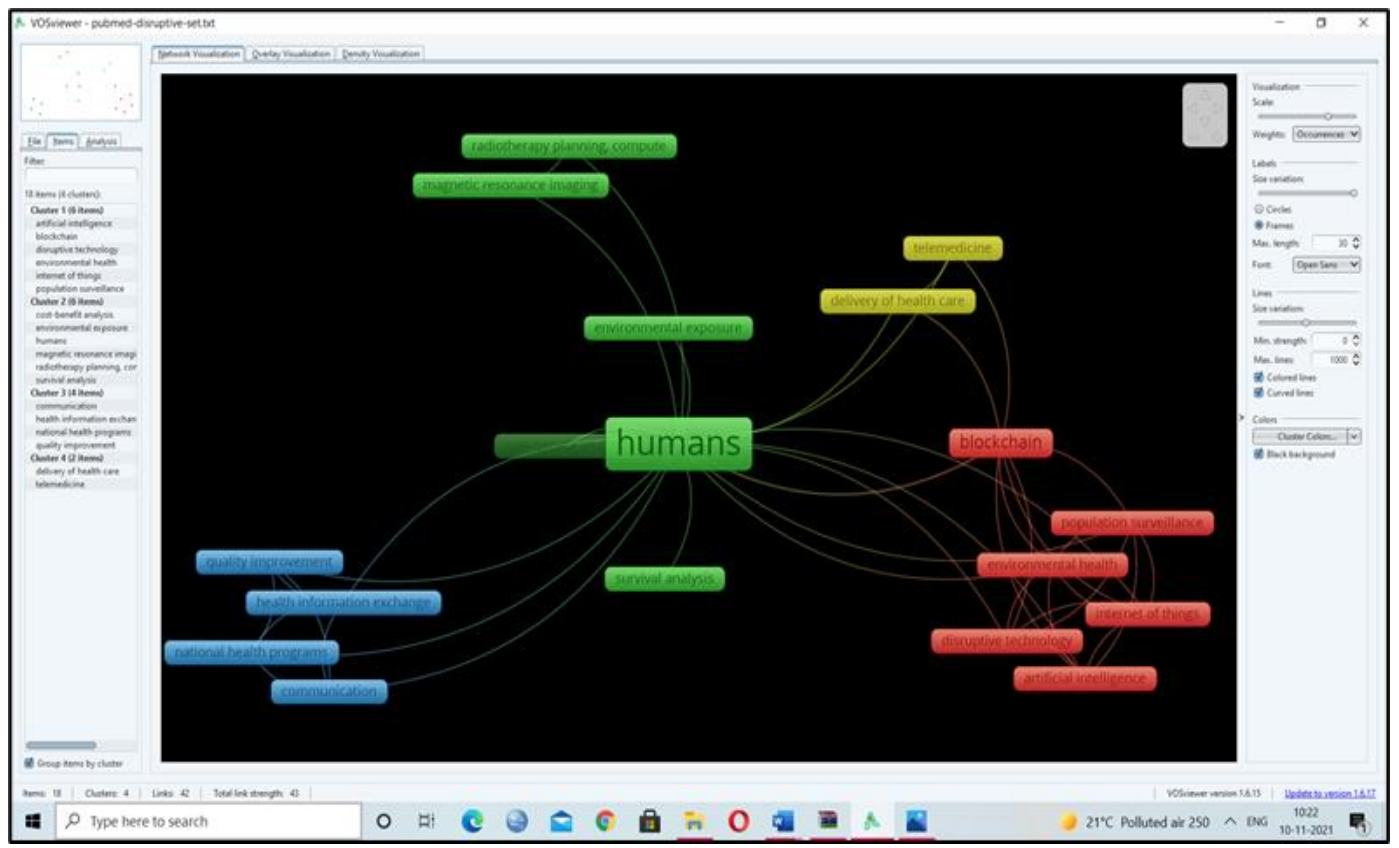

FIGURE 3- SELECTED ARTICLES PLOTTING AND DISTRIBUTION OF THE FREQUENT OCCURRED KEYWORDS AS A NETWORK

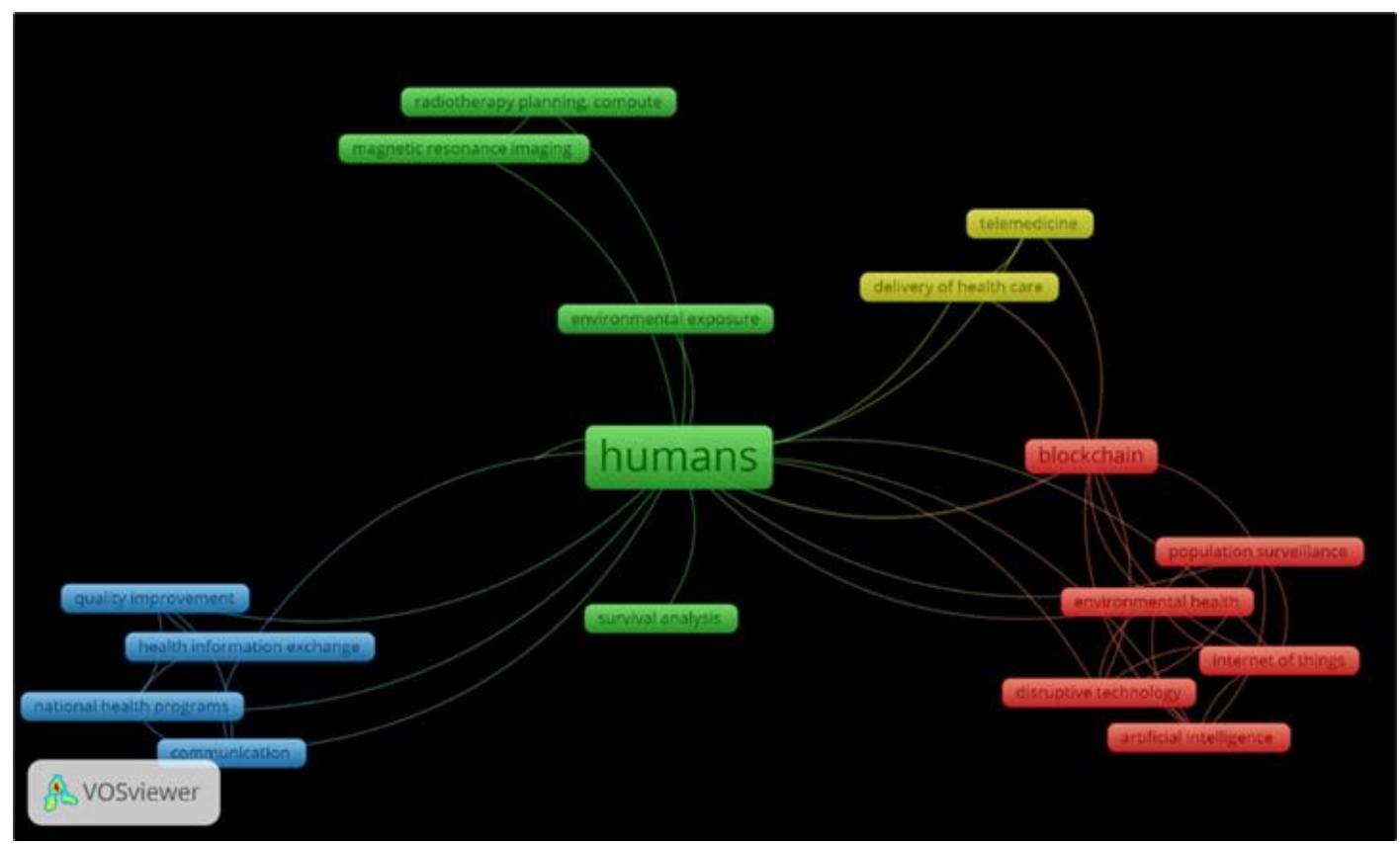




\begin{tabular}{|c|c|c|}
\hline S.NO. & NO. OF ITEMS IN CLUSTERS & FORMED CLUSTERS' DETAIL \\
\hline 1. & Cluster 1 ( 6 items) & $\begin{array}{ll}\text { - } & \text { Artificial intelligence } \\
\text { - } & \text { Blockchain } \\
\text { - } & \text { Eisruptive technology } \\
\text { - } & \text { Environmental health } \\
\text { - } & \text { Internet of things } \\
\text { - } & \text { Population surveillance }\end{array}$ \\
\hline 2. & Cluster 2 (6 items) & $\begin{array}{ll}\text { - } & \text { Cost-benefit analysis } \\
\text { - } & \text { Humans } \\
\text { - } & \text { Environmental health } \\
\text { - } & \text { Magnetic resonance imaging } \\
\text { - } & \text { Radiotherapy planning } \\
\text { - } & \text { Survival analysis }\end{array}$ \\
\hline 3. & Cluster 3 (4 items) & $\begin{array}{ll}\text { - } & \text { Communication } \\
\text { - } & \text { Health information exchange } \\
\text { - } & \text { National health programs } \\
\text { - } & \text { Quality improvement }\end{array}$ \\
\hline 4. & Cluster 4 (2 items) & $\begin{array}{ll}\text { - } & \text { Delivery of health care } \\
\text { - } & \text { Telemedicine }\end{array}$ \\
\hline
\end{tabular}

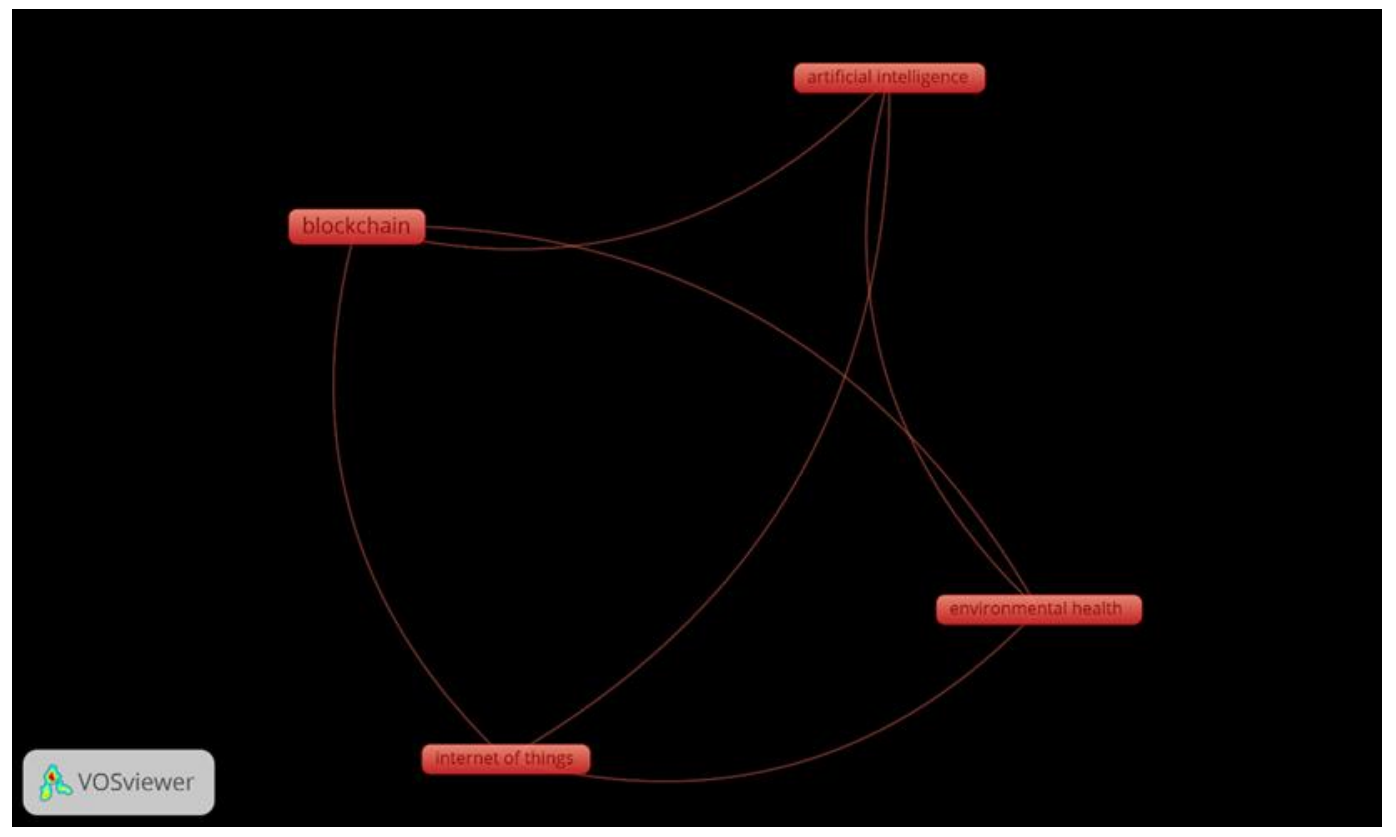


The research examined each disruptive technology in detail and determined how each will be used in environment studies as described below:

\section{INTERNET OF THINGS}

The loT is a rapidly developing concept of networking that seeks to transform the contemporary world today. The goal of IOT is to integrate many intelligent devices and linked networks into one large network. [7],[8]

\subsection{Internet of Things in the Environment}

Significant weather conditions, such as drastic increases in temperature, forest fires, and storms causing rivers, have a significant effect on wellbeing. People rely on the environment, and these developments have a significant impact on their wellbeing through improved dissemination and circulation of diseases and air pollution. [9]

IOT surveillance of the atmosphere and wellbeing will further strengthen the present perception of their relationship and contribute to possible ways to minimize harmful effects. The newest use in the environment for loT sensors involves mapping spatio-time information such as transport rates and pollutant sources and utilizing sensor gathered or consumer crowd-sourced data for epidemiological tracking. [10]

Sensors of air quality management are mainly used in outdoor or indoor tracking and personal monitoring. In addition to air quality, IoT technology also tracks and generates unhealthy radiation levels, noise, real-time water pollution charts, and temperature. [1 11$]$

\section{BLOCKCHAIN}

\subsection{Blockchain in Environment}

As in health, Blockchain can overcome problems of interoperability and data exchange, help facilitate decisions and maximize capital. Technology can also boost urgent environmental issues such as resources, climate change, natural hazards, degradation of ocean quality, and air pollution. A blockchain-enabled food monitoring solution will improve transparency in the production phase and allow consumers' eco-safe choices. Companies like IBM are also in the early stage of Blockchain's application of powered food chain technology. [12]

The present research has mentioned the ability of Blockchain to permit peer-to-peer trading. The Blockchain could contribute to the implementation of peer-to-peer energy sharing schemes in environmental scenarios in which consumers will exchange energy amongst themselves. The integration of Blockchain and loT sensors would help to render intensive care of air and water quality. The durability of the disruptive technology of Blockchain will assist natural catastrophes. [13]

\section{ARTIFICIAL INTELLIGENCE}

\subsection{Artificial Intelligence in Environment}

As climate change stems from human actions, environmental conditions that will affect our atmosphere and health care must be correctly forecasted. However, climate simulations are also somewhat different, mainly due to how data separated into distinct sections, the way processes and structures combine, and spatial and temporal scales as the broad spectrum. [14]

More specifically, Al often improves weather prediction and the forecast of severe weather incidents [5]. This is how they will apply new knowledge to cope with the environment's actual world complexity taking into consideration the nature of the weather and the seas and the atmosphere in their estimates. This increases weather and environment modelling performance, rendering forecasts for decision-makers more valuable. [15]

After doing the above assessment, the present study finds the below-mentioned review of articles to be critical to address the potential challenges and opportunities present in the study:

Technology has advanced at a breakneck pace throughout the years. 


\begin{tabular}{|c|c|c|c|c|c|c|}
\hline S. NO. & $\begin{array}{l}\text { TECHNOLO } \\
\text { GY }\end{array}$ & STUDY AREA & $\begin{array}{l}\text { RESEARCH } \\
\text { OBJECTIVE }\end{array}$ & CHALLENGES & OPPORTUNITIES & $\begin{array}{l}\text { REFERE } \\
\text { NCE }\end{array}$ \\
\hline 1. & $\begin{array}{l}\text { Internet of } \\
\text { Things }\end{array}$ & Environment & $\begin{array}{l}\text { As technology } \\
\text { advances, it is } \\
\text { becoming } \\
\text { even more } \\
\text { critical that } \\
\text { these lot } \\
\text { devices } \\
\text { become } \\
\text { autonomous to } \\
\text { allow long- } \\
\text { term } \\
\text { environmental } \\
\text { sensing } \\
\text { activity. }\end{array}$ & $\begin{array}{l}\text { With the Internet } \\
\text { of Things } \\
\text { becoming more } \\
\text { omnipresent } \\
\text { and } \\
\text { applications } \\
\text { becoming } \\
\text { creative, } \\
\text { independent } \\
\text { devices' ability } \\
\text { demands more } \\
\text { creativity. }\end{array}$ & $\begin{array}{l}\text { Energy injection } \\
\text { methods may be } \\
\text { used to include } \\
\text { sensing devices that } \\
\text { can function in } \\
\text { several settings where } \\
\text { natural energy } \\
\text { supplies are not or are } \\
\text { not large enough. }\end{array}$ & [16] \\
\hline 2. & $\begin{array}{l}\text { Internet of } \\
\text { Things }\end{array}$ & Environment & $\begin{array}{l}\text { This thesis } \\
\text { primarily aims } \\
\text { at systemic } \\
\text { research on } \\
\text { indoor air } \\
\text { pollution } \\
\text { management } \\
\text { technologies } \\
\text { that are } \\
\text { cutting-edge } \\
\text { and built on } \\
\text { the Internet of } \\
\text { Things. }\end{array}$ & $\begin{array}{l}\text { The } \\
\text { development of } \\
\text { useful IAQ } \\
\text { tracking } \\
\text { functionality } \\
\text { must be based } \\
\text { on given the } \\
\text { emerging } \\
\text { pandemic } \\
\text { scenario. }\end{array}$ & $\begin{array}{l}\text { Real-time living } \\
\text { climate reporting } \\
\text { supports public } \\
\text { security and well- } \\
\text { being }\end{array}$ & [2] \\
\hline 3. & Blockchain & Environment & $\begin{array}{l}\text { To discover } \\
\text { different } \\
\text { implementatio } \\
\text { ns of cyber- } \\
\text { physical } \\
\text { systems that } \\
\text { use } \\
\text { blockchain. }\end{array}$ & $\begin{array}{l}\text { The introduction } \\
\text { of blockchains } \\
\text { into the loT field } \\
\text { would satisfy the } \\
\text { need for } \\
\text { cryptographic } \\
\text { authentication, } \\
\text { affecting crucial } \\
\text { improvements } \\
\text { through various } \\
\text { industries. }\end{array}$ & $\begin{array}{l}\text { Smart grids, health } \\
\text { networks, and } \\
\text { industrial } \\
\text { manufacturing } \\
\text { systems are among } \\
\text { the many } \\
\text { applications that } \\
\text { blockchain } \\
\text { technology can } \\
\text { support. }\end{array}$ & [17] \\
\hline 4 & Blockchain & Environment & $\begin{array}{l}\text { When it comes } \\
\text { to } \\
\text { environmental } \\
\text { sustainability in } \\
\text { a globalised } \\
\text { society, what } \\
\text { role does the } \\
\text { blockchain } \\
\text { play? }\end{array}$ & $\begin{array}{l}\text { There may be } \\
\text { environmental } \\
\text { consequences } \\
\text { from } \\
\text { implementing } \\
\text { blockchain } \\
\text { technology, and } \\
\text { managers need } \\
\text { to be prepared. }\end{array}$ & $\begin{array}{l}\text { The recognition of the } \\
\text { importance of } \\
\text { blockchain } \\
\text { technologies in } \\
\text { environmental } \\
\text { sustainability offers } \\
\text { policymakers the } \\
\text { advice to stimulate } \\
\text { the development of } \\
\text { appropriate technical } \\
\text { infrastructure that } \\
\text { enables blockchain } \\
\text { execution and }\end{array}$ & [18] \\
\hline
\end{tabular}




\begin{tabular}{|c|c|c|c|c|c|c|}
\hline & & & & & $\begin{array}{l}\text { environmental } \\
\text { sustainability by } \\
\text { making this } \\
\text { technology easier to } \\
\text { use and disseminate } \\
\text { at both the public } \\
\text { and private sectors }\end{array}$ & \\
\hline 5. & $\begin{array}{l}\text { Artificial } \\
\text { Intelligence }\end{array}$ & Environment & $\begin{array}{l}\text { To discuss the } \\
\text { most recent } \\
\text { developments } \\
\text { in lontronic } \\
\text { Sensor } \\
\text { technology. }\end{array}$ & $\begin{array}{l}\text { A technology } \\
\text { that enhances } \\
\text { the human } \\
\text { sense of touch } \\
\text { with the } \\
\text { environment } \\
\text { beyond skin-like } \\
\text { sensation is } \\
\text { desired in } \\
\text { ambient } \\
\text { experiences. }\end{array}$ & $\begin{array}{l}\text { For the development } \\
\text { of wearable routes } \\
\text { and disposable } \\
\text { applications, a good } \\
\text { lontronic Sensing } \\
\text { principal signal-to- } \\
\text { noise ratio in low- } \\
\text { power electronics } \\
\text { may be crucial. }\end{array}$ & [19] \\
\hline 6 & $\begin{array}{l}\text { Artificial } \\
\text { Intelligence }\end{array}$ & Environment & $\begin{array}{l}\text { Artificial } \\
\text { Intelligence } \\
\text { influence on } \\
\text { the Sustainable } \\
\text { Development } \\
\text { Goals in the } \\
\text { Society group } \\
\text { examined. }\end{array}$ & $\begin{array}{l}\text { For Al's rapid } \\
\text { growth to be } \\
\text { sustainable, it } \\
\text { must be backed } \\
\text { by regulatory } \\
\text { knowledge and } \\
\text { control of Al- } \\
\text { based } \\
\text { technology. } \\
\text { Doing so might } \\
\text { lead to a lack of } \\
\text { transparency, } \\
\text { safety, and } \\
\text { ethical } \\
\text { standards. }\end{array}$ & $\begin{array}{l}\text { There must be an } \\
\text { Artificial intelligence } \\
\text { (Al) and its growing } \\
\text { effect on a variety of } \\
\text { industries on the } \\
\text { accomplishment of } \\
\text { the Sustainable } \\
\text { Development Goals. }\end{array}$ & [20] \\
\hline
\end{tabular}

\section{CONCLUSION}

Various stakeholders from many different fields and disciplines are encouraged to join forces to broaden reporting and monitoring programmes on environmental effects on human safety in the interest of the well-being of people, according to the present study. Data management, safety, and security standards must be addressed before effective monitoring systems can be adopted, according to the conclusions of this study. There has been a dramatic increase in the general population's awareness and adaptability to new technologies and technological regimes.
Though the possibilities of IOT, blockchain, and Al all have the potential to accelerate the integration of environmental data, they all face certain drawbacks and difficulties when it comes to environmental monitoring, which should be prioritized. This research explored the current use of three emerging technologies - remote surveillance, surveillance, and a requirement for an enhanced computer architecture - to better address the needs of pilot and tracking operations. The focused efforts to assess a variety of scholarly publications and government reports, as well as the technological infrastructure's suggestions for management and operations, provide intriguing information for further study. 


\section{References}

1. S. E. Bibri, "On the sustainability of smart and smarter cities in the era of big data: an interdisciplinary and transdisciplinary literature review," J. Big Data, vol. 6, no. 1, 2019.

2. J. Saini, M. Dutta, and G. Marques, "Indoor air quality monitoring systems based on internet of things: A systematic review," Int. J. Environ. Res. Public Health, vol. 17, no. 14, pp. 1-22, 2020.

3. G. Madaan, H. R. Swapna, A. Kumar, A. Singh, and A. David, "Enactment of sustainable technovations on healthcare sectors," Asia Pacific J. Heal. Manag., vol. 16, no. 3, pp. 1-9, 2021.

4. A. Kumar and N. Ayedee, "An interconnection between COVID-19 and climate change problem," J. Stat. Manag. Syst., vol. 24, no. 2, pp. 281-300, 2021.

5. A. Kumar, "Artificial Intelligence: Technology 4.0 as a solution for healthcare workers during COVID-19 pandemic," Acta Univ. Bohemiae Merid., vol. 24, no. 1, pp. 23-42, 2021.

6. L. Groenink, P. M. Verdouw, B. Bakker, and K. E. Wever, "Pharmacological and methodological aspects of the separation-induced vocalization test in guinea pig pups; A systematic review and meta-analysis," Eur. J. Pharmacol., vol. 7, no. 11, pp. 191-208, 2014.

7. J. Gomez-Marquez and K. Hamad-Schifferli, "Distributed Biological Foundries for Global Health," Adv. Healthc. Mater., vol. 8, no. 18, pp. 1-19, 2019.

8. S. Dash, S. K. Shakyawar, M. Sharma, and S. Kaushik, "Big data in healthcare: management, analysis and future prospects," J. Big Data, vol. 6, no. 1, 2019.

9. I. Manisalidis, E. Stavropoulou, A. Stavropoulos, and E. Bezirtzoglou, "Environmental and Health Impacts of Air Pollution: A Review," Front. Public Heal., vol. 8, no. February, pp. 1-13, 2020.

10. H. Nissan et al., "On the use and misuse of climate change projections in international development," Wiley Interdiscip. Rev. Clim. Chang., vol. 10, no. 3, pp. 1-16, 2019.

11. C. D. Butler, "Climate change, health and existential risks to civilization: A comprehensive review (19892013)," Int. J. Environ. Res. Public Health, vol. 15, no. 10, 2018.
12. V. Paliwal, S. Chandra, and S. Sharma, "Blockchain technology for sustainable supply chain management: A systematic literature review and a classification framework," Sustain., vol. 12, no. 18, pp. 1-39, 2020.

13. F. M. Bublitz et al., "Disruptive technologies for environment and health research: An overview of artificial intelligence, blockchain, and internet of things," Int. J. Environ. Res. Public Health, vol. 16, no. 20, pp. 1-24, 2019.

14. L. Morawska et al., "Applications of low-cost sensing technologies for air quality monitoring and exposure assessment: How far have they gone?," Environ. Int. vol. 116, no. February, pp. 286-299, 2018.

15. E. Ntoutsi et al., "Bias in data-driven artificial intelligence systems-An introductory survey," Wiley Interdiscip. Rev. Data Min. Knowl. Discov., vol. 10, no. 3, pp. 1-14, 2020.

16. J. Curry and N. Harris, "Powering the environmental internet of things," Sensors (Switzerland), vol. 19, no. 8, 2019.

17. H. Rathore, A. Mohamed, and M. Guizani, "A survey of blockchain enabled cyber-physical systems," Sensors (Switzerland), vol. 20, no. 1, pp. 1-28, 2020.

18. A. Parmentola, A. Petrillo, I. Tutore, and F. De Felice, "Is blockchain able to enhance environmental sustainability? A systematic review and research agenda from the perspective of Sustainable Development Goals (SDGs)," Bus. Strateg. Environ., no. April, pp. 1-24, 2021

19. M. T. Nguyen, L. H. Truong, and T. T. H. Le, "Video Surveillance Processing Algorithms utilizing Artificial Intelligent (Al) for Unmanned Autonomous Vehicles (UAVs)," MethodsX, vol. 8, p. 101472, 2021.

20. R. Vinuesa et al., "The role of artificial intelligence in achieving the Sustainable Development Goals," Nat. Commun., vol. 11, no. 1, pp. 1-10, 2020. 